\title{
MAPK signaling mediates sinomenine hydrochloride- induced human breast cancer cell death via both reactive oxygen species-dependent and -independent pathways: an in vitro and in vivo study
}

\author{
X Li ${ }^{1}$, K Wang ${ }^{1}$, Y Ren ${ }^{1}$, L Zhang ${ }^{1}$, X-J Tang ${ }^{1}$, H-M Zhang ${ }^{1}$, C-Q Zhao ${ }^{2}$, P-J Liü ${ }^{3}$ J-M Zhang ${ }^{3,4}$ and J-J He ${ }^{\star, 1}$
}

Sinomenine, the main alkaloid extracted from the medicinal plant Sinomenium acutum, is known for its anti-inflammatory effects. Recent studies have suggested its anti-cancer effect in synovial sarcoma, lung cancer and hepatic cancer. However, the underlying molecular mechanism for its anti-cancer effect still remains unclear. This study investigated the anti-tumor activity of sinomenine hydrochloride (SH), a hydrochloride form of sinomenine, in human breast cancer cells in vitro and in vivo. We found that SH potently inhibited cell viability of a broad panel of breast cancer cell lines. Two representative breast cancer cell lines, namely ER( - )/PR( - ) MDA-MB-231 and ER( + )/PR( + ) MCF-7, were used for further investigation. The results showed that SH induced G1/S cell cycle arrest, caused apoptosis and induced ATM/Chk2- and ATR/Chk1-mediated DNA-damage response in MDA-MB-231 and MCF-7. The anti-cancer effect of SH was regulated by increased expression levels of p-ERK, p-JNK and p-38 MAPK. Further studies showed that SH resulted in an increase in reactive oxygen species (ROS) and inhibition of ROS by $\mathrm{N}$-acetyl-L-cysteine (NAC) almost blocked SH-induced DNA damage but only mitigated SH-induced MAPK expression changes, suggesting that both ROS-dependent and -independent pathways were involved in MAPK-mediated SH-induced breast cancer cell death. The in vivo study demonstrated that SH effectively inhibited tumor growth without showing significant toxicity. In conclusion, SH induced breast cancer cell death through ROS-dependent and -independent pathways with an upregulation of MAPKs, indicating that SH may be a potential anti-tumor drug for breast cancer treatment.

Cell Death and Disease (2014) 5, e1356; doi:10.1038/cddis.2014.321; published online 31 July 2014

In recent decades, breast cancer is increasing in both developed and developing countries. ${ }^{1-3}$ Breast cancer has become the most common cancer and the leading cause of death in women all over the world. ${ }^{4}$ Although current strategies targeting breast cancer have improved markedly, breast cancer patients often develops metastasis ${ }^{5}$ and drug resistance. ${ }^{6}$ Therefore, it is necessary to search for new effective therapies for breast cancer treatment.

Plants are one of the most important sources of compounds for chemoprevention and $>60 \%$ of cancer therapeutics on the market or in preclinical trials are based on natural products. ${ }^{7,8}$ The medicinal plant Sinomenium acutum Rehd. et Wils. (Fam. Menispermaceae) has been used to effectively treat rheumatoid arthritis for centuries in the Far East. ${ }^{9}$ Since its main effective component sinomenine (7,8-didehydro-4-hydroxy-3, 7-dimethoxy-17-methylmorphinan-6-one, C19H23NO4, molecular weight: $329.38 \mathrm{Da}$, Figure 1a), a pure alkaloid, was extracted from the plant, numerous studies have been conducted on its underlying mechanisms for rheumatoid arthritis treatment ${ }^{10,11}$ and other possible pharmacological effects, such as attenuation of ischemia/reperfusion injury, ${ }^{12,13}$ treatment of neurodegenerative disorders ${ }^{14}$ and reduction of analgesic tolerance. $^{15}$ Sinomenine hydrochloride (SH, Figure 1b), a hydrochloride chemical form of sinomenine, is widely used in clinical treatment of rheumatoid diseases for its anti-inflammatory and anti-immune effects. ${ }^{16}$ Recently, its anti-tumor activity has been found in synovial sarcoma, lung cancer and hepatic cancer; ${ }^{17-19}$ however, the molecular mechanisms and the signaling pathways of $\mathrm{SH}$ against cancer are still not clarified, and no studies have investigated whether $\mathrm{SH}$ could induce breast cancer cell death.

There exist seven classes of mitogen-activated protein kinase (MAPK) intracellular signaling cascades, and four of them are implicated in breast diseases and function in mammary epithelial cells, including the extracellular-regulated kinase (ERK)1/2 pathway, the c-Jun N-terminal kinase (JNK) pathway, the 38 MAPK pathway and the ERK5 pathway. ${ }^{20}$ In this study, we especially focused on three prominent MAPK pathways, namely ERK1/2, JNK and p38. Milde-Langosch et al. $^{21}$ have pointed out in a clinical study that high

\footnotetext{
${ }^{1}$ Department of Surgical Oncology, First Affiliated Hospital of Xi'an Jiaotong University, 277 West Yanta Road, Xi'an, P.R. China; ${ }^{2}$ Key Laboratory of Cell Proliferation and Regulation Biology, College of Life Science, Beijing Normal University, Beijing, P.R. China; ${ }^{3}$ Translational Medical center, First Affiliated Hospital of Xi'an Jiaotong University, 277 West Yanta Road, X''an, P.R. China and ${ }^{4}$ Department of Cancer Genetics, Roswell Park Cancer Institute, Elm and Calton Streets, Buffalo, NY, USA ${ }^{*}$ Corresponding author: J-J He, Department of Surgical Oncology, First Affiliated Hospital of Xi'an Jiaotong University, 277 West Yanta Road, Xi'an 710061, P.R. China. Tel/Fax: +86 29 85324609; E-mail: chinahjj@163.com

Abbreviations: SH, sinomenine hydrochloride; MAPK, mitogen-activated protein kinase; ERK, extracellular-regulated kinase; JNK, c-Jun N-terminal kinase; ROS, reactive oxygen species; NAC, N-acetyl-L-cysteine; ER, estrogen receptor; PR, progesterone receptor; $\Delta \psi \mathrm{m}$, mitochondrial membrane potential; DDR, DNA-damage response; DSB, double-strand break; $\gamma \mathrm{H} 2 \mathrm{AX}$, phosphorylation at Ser139 of $\mathrm{H} 2 \mathrm{AX}$

Received 27.3.14; revised 24.6.14; accepted 26.6.14; Edited by A Stephanou
} 
a<smiles>COC1=CC2(C)[C@@H]3Cc4ccc(OC)c(O)c4[C@@]2(CC1=O)CN3C</smiles>

b

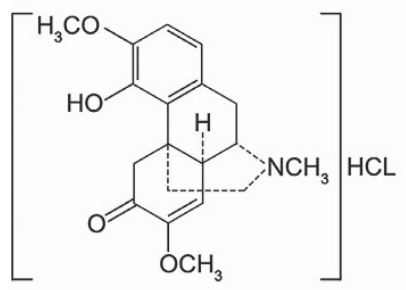

d
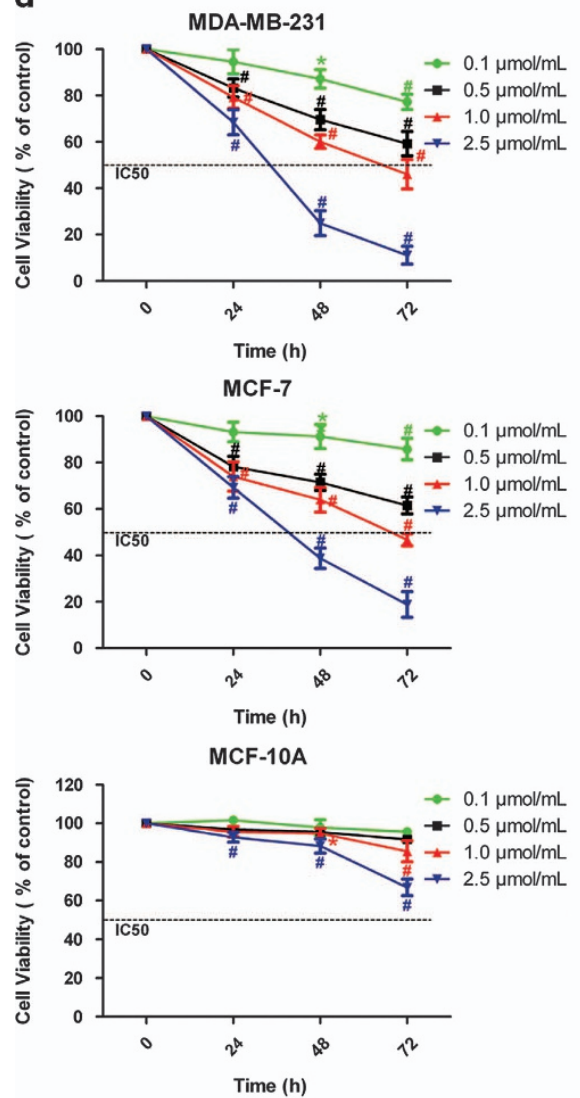

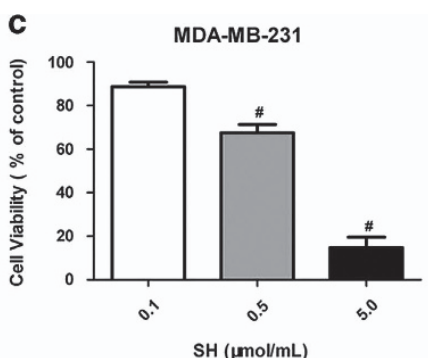

ZR-75-30

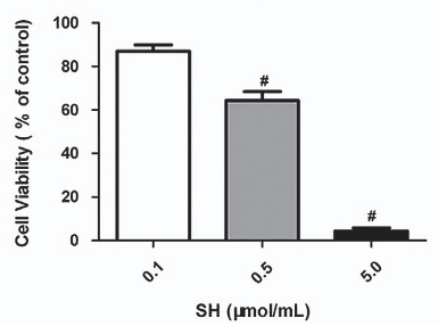

e

e

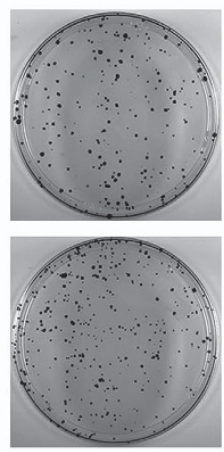

0

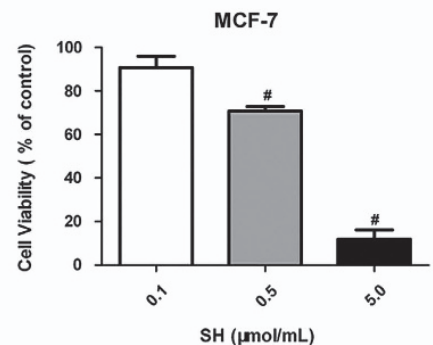

BT474

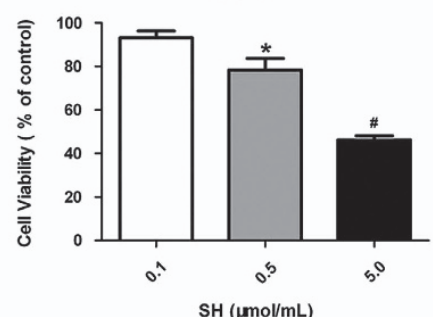

$\mathrm{SH}(\mu \mathrm{mol} / \mathrm{mL})$

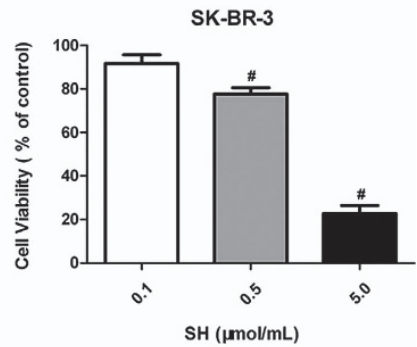

$\mathrm{SH}(\boldsymbol{\mu m o l} / \mathrm{mL})$

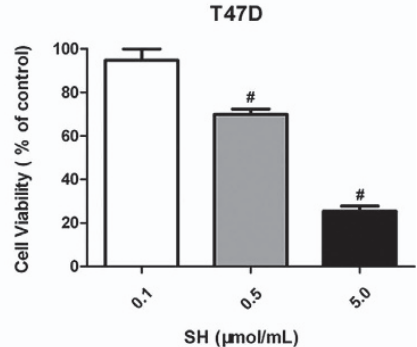

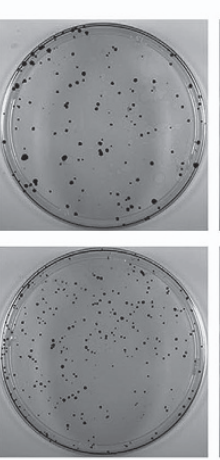

0.25

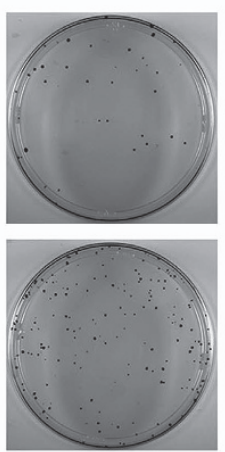

0.5

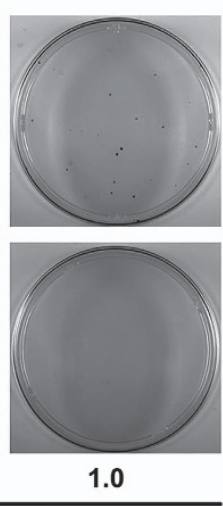

$\mathrm{SH}(\mu \mathrm{mol} / \mathrm{mL})$

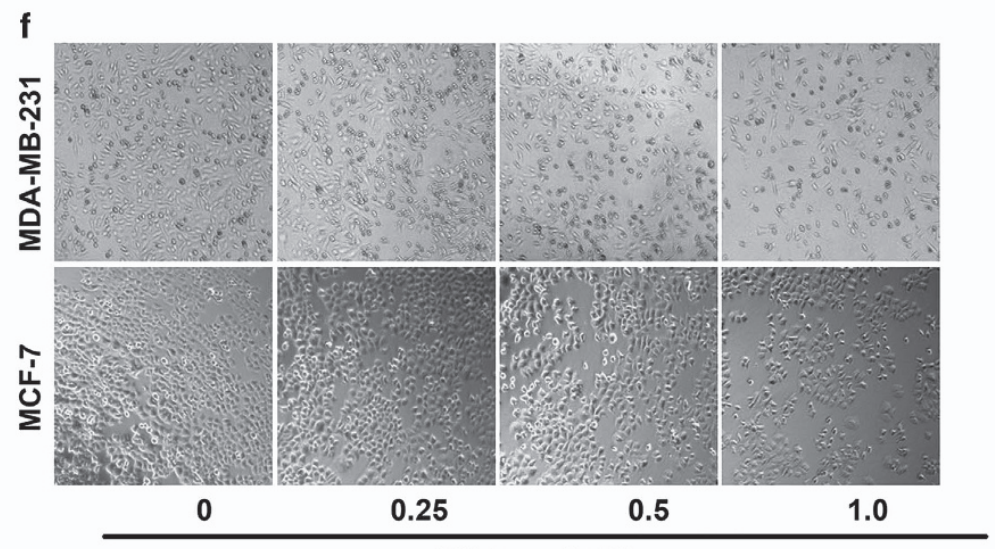

$\mathrm{SH}(\mu \mathrm{mol} / \mathrm{mL})$

Figure 1 SH inhibited human breast cancer cell viability. Chemical structures of (a) sinomenine and (b) SH. (c) A panel of human breast cancer cell lines (MDA-MB-231, MCF-7, SK-BR-3, ZR-75-30, BT474 and T47D) were treated with SH (0, 0.1, 0.5 and $5.0 \mu \mathrm{mol} / \mathrm{ml})$ for $48 \mathrm{~h}$. Cell viability was measured by MTT assay. (d) Time-dependent inhibition of SH was evaluated by MTT assay. Data are represented as mean \pm S.D. of three independent experiments. ${ }^{*} P<0.05$, ${ }^{\#} P<0.01$, SH-treated group compared with the untreated control group. (e) Cell colony formation was evaluated by clonogenic assay. (f) Morphology changes of breast cancer cells treated with SH. Representative data from three independent experiments are shown 
phosphorylated ERK proteins are good prognostic indicators in breast cancer. Sustained phosphorylation of p38 and JNK in breast cancer cells are also involved in anti-cancer treatment. $^{22}$ Considering the important roles of MAPKs in breast cancer progression and cell proliferation, we hypothesized that $\mathrm{SH}$ inhibited breast cancer growth via modulation of MAPK pathways.

In this study, we first demonstrated the anti-proliferative effect of $\mathrm{SH}$ on breast cancer cells in vitro and in vivo. We found that $\mathrm{SH}$ induced $\mathrm{G} 1 / \mathrm{S}$ cell cycle arrest, caused cell apoptosis and triggered oxidative DNA damage in breast cancer cells. The results also demonstrated that $\mathrm{SH}$ induced breast cancer cell death by upregulating MAPK pathways and increasing intracellular reactive oxygen species (ROS) generation. The ROS scavenger $\mathrm{N}$-acetyl-L-cysteine (NAC) almost blocked SH-induced DNA damage but only mitigated $\mathrm{SH}$-induced MAPK expression changes, indicating that both ROS-dependent and -independent pathways were involved in the MAPK-mediated anti-cancer effect of $\mathrm{SH}$.

\section{Results}

SH inhibits breast cancer cell viability. To investigate the effect of SH on breast cancer cell viability, a panel of breast cancer cell lines were treated with $\mathrm{SH}$ for $48 \mathrm{~h}$, and cell viability was assessed by MTT assay. The results showed that $\mathrm{SH}$ inhibited all breast cancer cell lines, although to a different extent (Figure 1c). Estrogen receptor (ER) status and progesterone receptor (PR) status are clinically used breast cancer markers as they have an important role in indicating prognosis. Therefore, two representative breast cancer cell lines, namely $\mathrm{ER}(-) / \mathrm{PR}(-)$ cell line MDA-MB231 and $\mathrm{ER}(+) / \mathrm{PR}(+)$ cell line MCF-7 were selected to further investigate the anti-proliferative effect of $\mathrm{SH}$ on breast cancer cells. The MTT results showed that $\mathrm{SH}$ decreased cell viability of MDA-MB-231 and MCF-7 in a time-dependent manner (Figure 1d). Besides, one normal breast epithelial cell line MCF-10A was chosen to evaluate the selective toxicity of $\mathrm{SH}$. The $50 \%$ growth inhibitory concentrations $\left(\mathrm{IC}_{50}\right)$ for MDA-MB-231, MCF-7 and MCF-10A at $48 \mathrm{~h}$ were 1.33, 1.51 and $5.21 \mu \mathrm{mol} / \mathrm{ml}$, respectively, indicating that in comparison with normal human breast epithelial cells $\mathrm{SH}$ may have a more selective toxic effect on neoplastic cells. In the following experiments, MDA-MB-231 and MCF-7 were treated with $\mathrm{SH}$ at the concentrations of $0.25,0.5$ and $1.0 \mu \mathrm{mol} / \mathrm{ml}$, which were selected according to their respective $\mathrm{IC}_{50}$ values.

To evaluate the long-term effect of $\mathrm{SH}$ on cancer cell survival, colony-formation assays were performed. As shown in Figure 1e, at the concentration of $1.0 \mu \mathrm{mol} / \mathrm{ml}$ of $\mathrm{SH}$, almost no colonies were formed, demonstrating that the reproductive potentials of the two cell lines were significantly inhibited by $\mathrm{SH}$, in comparison with that of the control group. Figure if showed the cell morphology changes after treatment with $\mathrm{SH}$. After SH treatment, the number of cells decreased, and cells became rounded and detached from the bottle, which was especially obvious at $1.0 \mu \mathrm{mol} / \mathrm{ml}$ of $\mathrm{SH}$.

We wondered whether the anti-proliferative effect of $\mathrm{SH}$ was a common feature for other mammalian cancer cell lines. Two representative cell lines of lung cancer, gastric cancer, hepatic cancer, renal cancer, cervical cancer and colon cancer were selected and treated with $\mathrm{SH}$ for $48 \mathrm{~h}$. The antiproliferative effect of $\mathrm{SH}$ on these cell lines were measured by MTT assay. The results demonstrated that $\mathrm{SH}$ inhibited cell viability in various human cancer cells, although to varying degrees (Supplementary Figure S1).

SH induces G1/S cell cycle arrest in breast cancer cells. To further explore the effect of $\mathrm{SH}$ on cell cycle, cell cycle distribution was analyzed with propidium iodide (PI). Treatment of MDA-MB-231 and MCF-7 with SH resulted in an increased percentage of cell population in G0/G1 phase and a decreased percentage in $\mathrm{S}$ and G2/M phases (Figures $2 a$ and $b$ ). G1-to-S phase transition is strictly regulated by a series of proteins, including cyclins, cyclin-dependent kinases and cyclin-dependent kinase inhibitor proteins. We then explored the changes in proteins involved in G1/S transition by western blotting analysis. As shown in Figure $2 \mathrm{C}$ and Supplementary Figure S5a, decreased expression levels of cyclin D1, cyclin E, cdk4, MCM7 and phosphorylated Rb were observed, whereas increased expression levels of p21 and p27 were found. These changes were especially obvious when cells were treated with $\mathrm{SH}$ at $1.0 \mu \mathrm{mol} / \mathrm{ml}$, although to a different extent in these two cell lines. However, no changes were found in the expression levels of $R b$ and $p 53$, and $\mathrm{SH}$ did not cause the phosphorylation of p53 at Ser15 (a sample from Cell Signaling Technology was used as a positive control Supplementary Figure S2), indicating a p53-independent pathway in $\mathrm{SH}$-induced cell death. As cells in senescence state may also enter into a non-proliferative state and go through cell cycle arrest, we then investigated whether $\mathrm{SH}$ caused cellular senescence in breast cancer cells. Our results showed that $\mathrm{SH}$ did not induce cellular senescence in MDA-MB-231 and MCF-7 (Supplementary Figure S3).

\section{SH causes cell apoptosis via mitochondrial-dependent} way. AnnexinV-FITC/PI flow cytometry was used to assess the effect of $\mathrm{SH}$ on cell apoptosis. In Figure 3a, the fourth quadrant (Q4) represents early apoptotic cells and the second quadrant $(\mathrm{Q} 2)$ represents late apoptotic and necrotic cells. The results showed that the treatment with $\mathrm{SH}$ induced increased levels of both early apoptosis and late apoptosis and necrosis in MDA-MB-231 and MCF-7 cells. Treatment with $\mathrm{SH}$ at $1.0 \mu \mathrm{mol} / \mathrm{ml}$ resulted in a greater percentage of apoptosis in MDA-MB-231 than that in MCF-7 populations (Figure 3b). To reveal the $\mathrm{SH}$-induced apoptosis in breast cancer cells in detail, mitochondrial membrane potential $(\Delta \psi \mathrm{m})$, caspase activity and some proteins were examined.

$\Delta \psi \mathrm{m}$ is measured by a fluorescent probe JC- 1 . When $\Delta \psi \mathrm{m}$ is high, JC-1 aggregates and gives a red fluorescence. However, when $\Delta \psi \mathrm{m}$ is collapsed, it forms monomers and gives a green fluorescence. As Figure $3 c$ shows, the ratio of green/red intensity increased remarkably with $\mathrm{SH}$ treatment, suggesting that the mitochondrial function was dysregulated. As caspase-3, -8 and -9 have an important role in mitochondrial apoptotic signaling, ${ }^{23}$ we then explored whether caspase-3, -8 and -9 were activated after $\mathrm{SH}$ treatment. Experiments showed that caspase- 3 and -9 activities were 


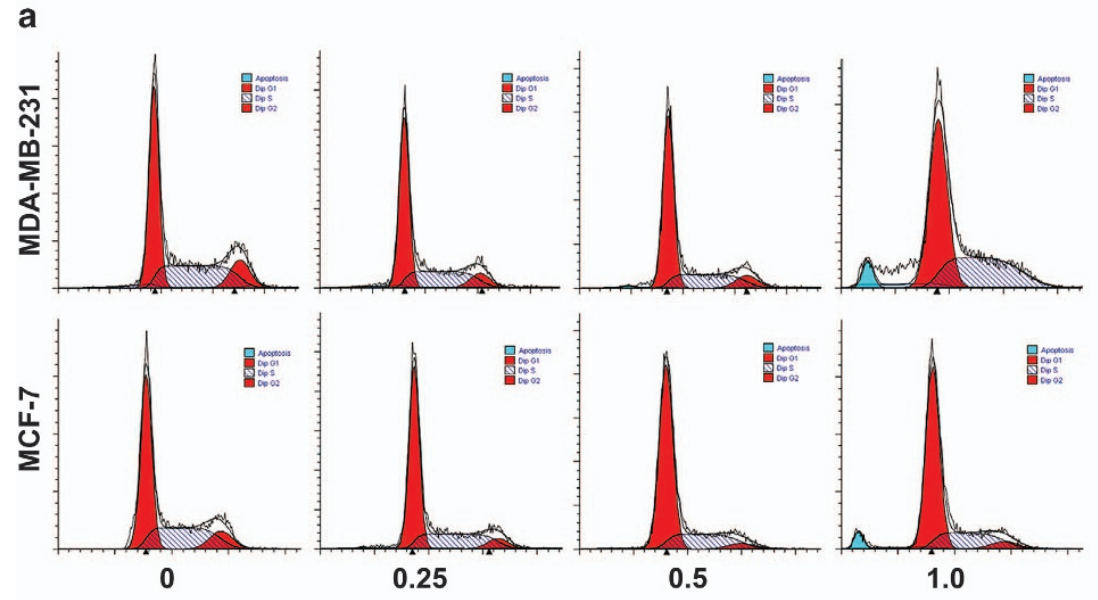

C

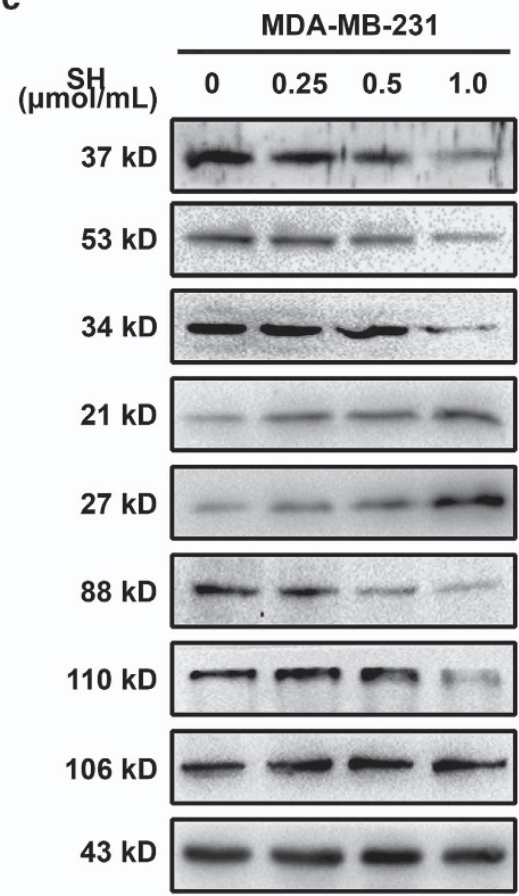

b

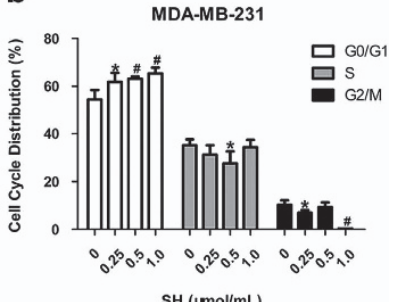

$\mathrm{SH}(\boldsymbol{\mu m o l} / \mathrm{mL})$

MCF-7

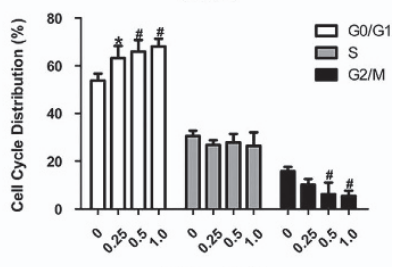

$\mathrm{SH}(\boldsymbol{\mu m o l} / \mathrm{mL})$

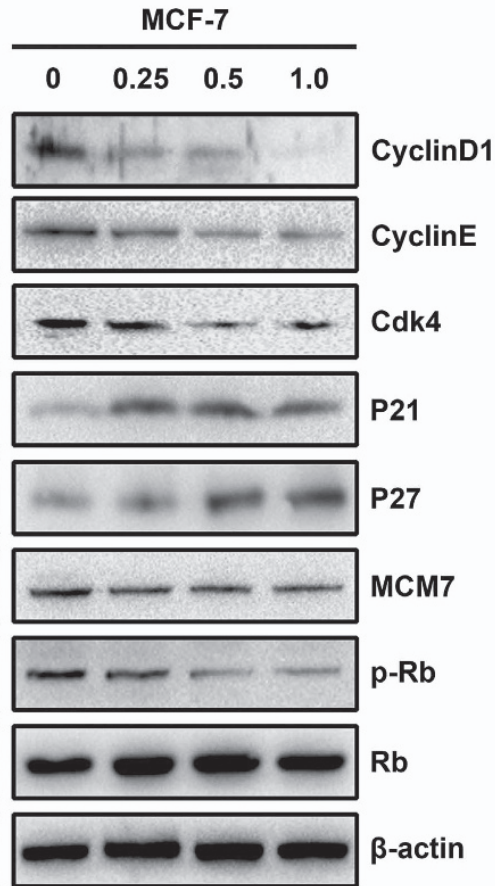

Figure $2 \mathrm{SH}$ induced G1/S cell cycle arrest in human breast cancer cells. (a and $\mathbf{b}$ ) Cells were treated with $\mathrm{SH}$ for $48 \mathrm{~h}$ and subjected to DNA content analysis using a FACSCAN flow cytometer. (c) Proteins involved in G1/S transition were analyzed by western blotting. Cells were treated with SH $(0,0.25,0.5 \mathrm{and} 1.0 \mu \mathrm{mol} / \mathrm{ml})$ for $48 \mathrm{~h}$, and total proteins were extracted. Equal protein loading was evaluated by $\beta$-actin. Data are represented as mean \pm S.D. of three independent experiments. ${ }^{*} P<0.05,{ }^{\#} P<0.01$, $\mathrm{SH}$-treated group compared with the untreated control group

enhanced, whereas no significant change in caspase-8 activity was found (Figure $3 \mathrm{~d}$ ). We then examined some proteins involved in apoptosis. The disruption of $\Delta \psi \mathrm{m}$ will release cytochrome $c$ from the mitochondrial intermembrane space into the cytoplasm. We found that $\mathrm{SH}$ treatment increased cytosolic cytochrome $c$ in MDA-MB-231 and MCF-7 (Figure $3 e$ and Supplementary Figure S5b). To understand how $\mathrm{SH}$ facilitated the apoptosis of breast cancer cells, the expression levels of anti-apoptotic protein Bcl-2, pro-apoptotic protein Bax and apoptotic marker PARP were examined. The western blotting analysis demonstrated an increase in cleaved PARP and $\mathrm{Bax} / \mathrm{Bcl}-2$ ratio (Figure $3 f$ and Supplementary Figure S5b).
SH triggers DNA damage in breast cancer cells. As cell cycle arrest and apoptosis are part of DNA-damage response (DDR), we then examined whether $\mathrm{SH}$ could induce DNA damage in breast cancer cells. It is known that one of the early cellular responses to DNA double-strand breaks (DSBs) is the phosphorylation at Ser139 of H2AX $(\gamma \mathrm{H} 2 \mathrm{AX}) .{ }^{24}$ Immunofluorescence staining results showed that $\gamma \mathrm{H} 2 \mathrm{AX}$ formed foci in the nuclear (Figure 4a). To verify the induction of DNA damage by $\mathrm{SH}$, phosphorylation of $\mathrm{H} 2 \mathrm{AX}$ was also measured by western blotting (Figure $4 \mathrm{~b}$ and Supplementary Figure S5c).

DNA damage initiates checkpoint responses that moderate cell cycle progression for DNA repair. ATM/ATR-Chk1/Chk2 

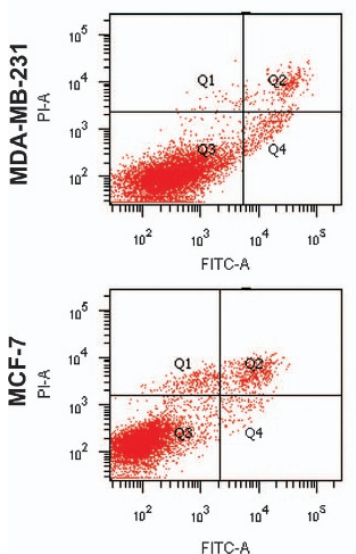

0
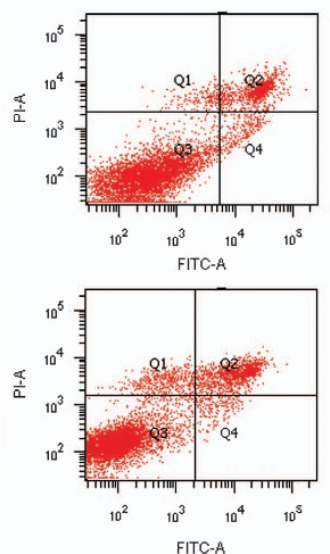

0.25
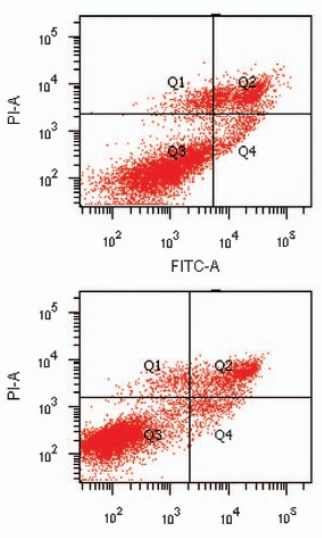

0.5
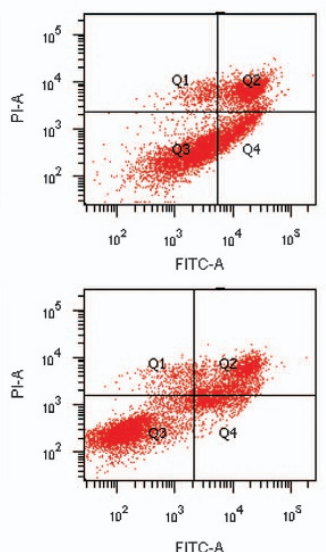

1.0 $\mathrm{SH}(\mu \mathrm{mol} / \mathrm{mL})$

b

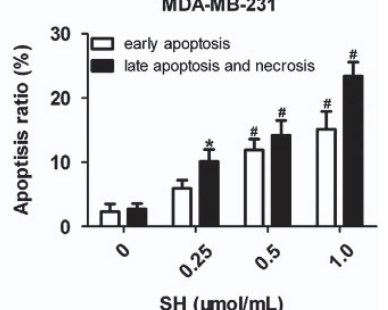

MCF-7

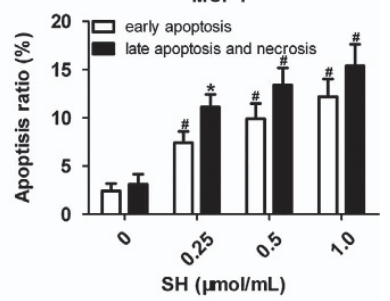

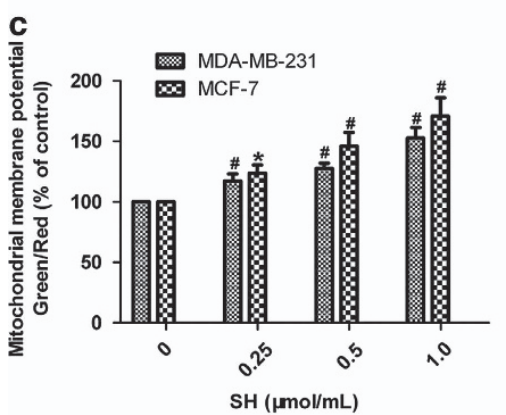

d
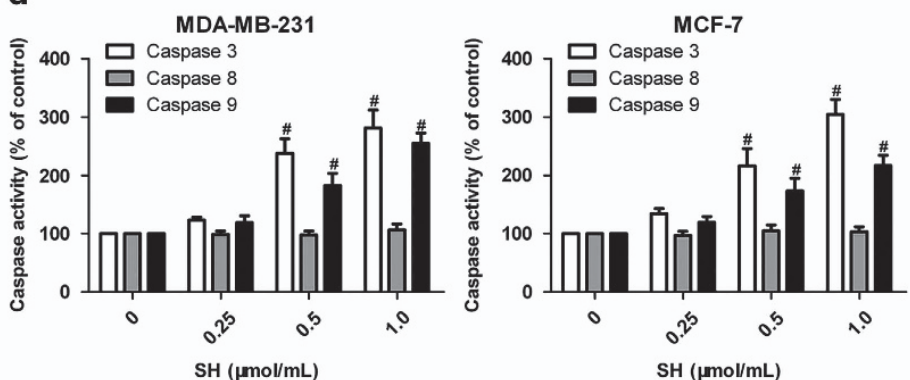

e
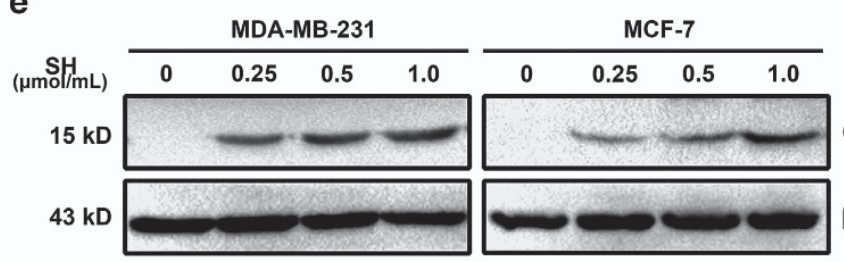

Cytochrome c

f
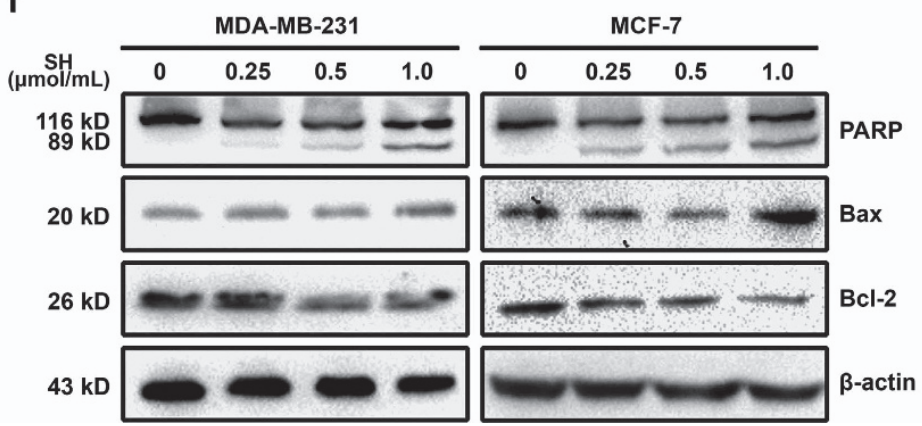

Figure 3 SH induced apoptosis in human breast cancer cells. (a and b) Cells were treated with SH for $48 \mathrm{~h}$ and analyzed using AnnexinV-FITC/PI flow cytometry. (c) $\Delta \psi \mathrm{m}$ was evaluated by flow cytometric analysis of JC-1. Cells were treated with SH for $48 \mathrm{~h}$ and stained with JC-1. Green/red fluorescence intensity value was calculated. (d) Cells were treated with SH for $48 \mathrm{~h}$ and caspase- $3,-8$ and -9 were assessed by Caspase- $3,-8$ and -9 Colorimetric Assays. Each value is expressed as the ratio of caspase activation level to control level, and the value of the control was set to 100. (e) SH increased the release of cytochrome $c$ from the mitochondria into the cytoplasm. Cells were treated with $\mathrm{SH}$, and cytosolic fraction was used for western blotting. (f) Apoptosis-related proteins, PARP, Bax and Bcl-2, were analyzed by western blotting. Cells were treated with SH for $48 \mathrm{~h}$, and total proteins were extracted. Equal protein loading was evaluated by $\beta$-actin. Data are the means \pm S.D. of three independent experiments. ${ }^{*} P<0.05$, ${ }^{\#} P<0.01$, $\mathrm{SH}$-treated group compared with the untreated control group 
a

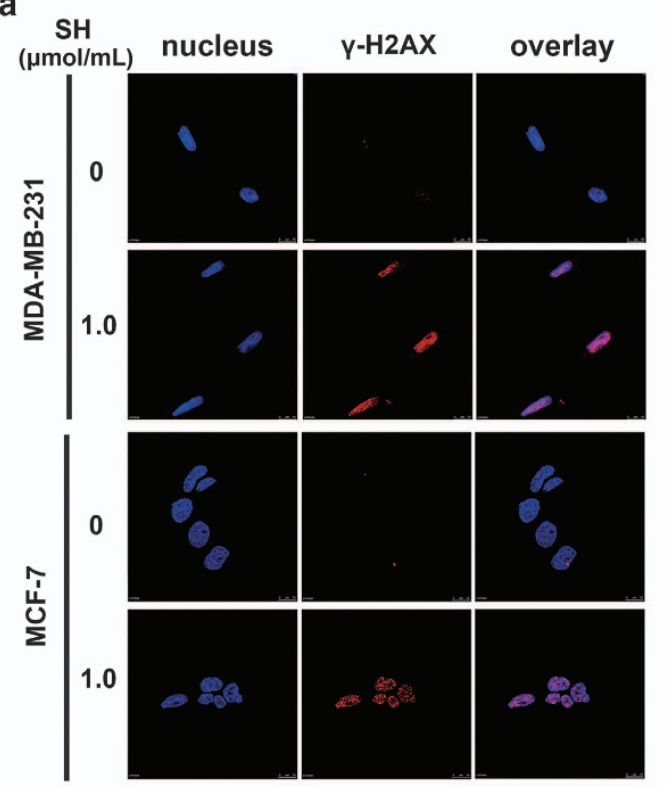

C

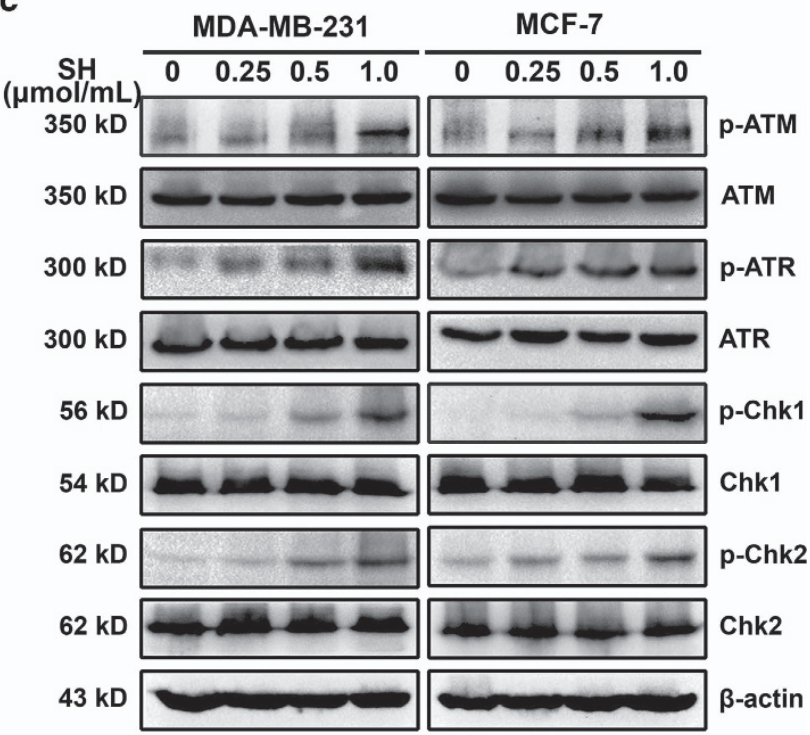

b

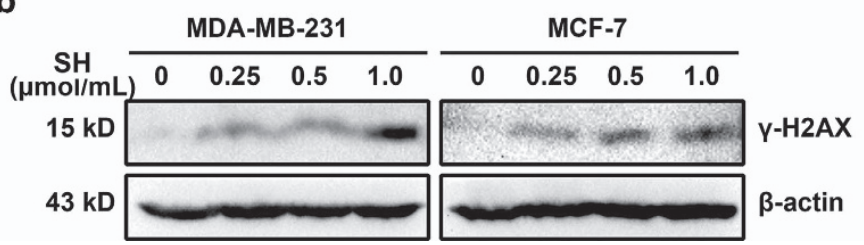

Figure 4 SH induced DNA damage in human breast cancer cells. (a) $\gamma \mathrm{H} 2 \mathrm{AX}$ foci was detected by immunofluorescence. (b) $\gamma \mathrm{H} 2 \mathrm{AX}$ expression was analyzed by western blotting. (c) The potential involvement of DNA damage response pathways were evaluated using western blotting. Equal protein loading was evaluated by $\beta$-actin. Representative data from three independent experiments were shown

signaling pathways are important in DDR. To figure out the underlying signaling pathways by which $\mathrm{SH}$ regulated DNA damage, we examined the molecular changes by western blotting. As Figure $4 \mathrm{C}$ and Supplementary Figure S5c show, after treatment with $\mathrm{SH}$ for $48 \mathrm{~h}$, an increase in the protein levels of phospho-ATM and phospho-ATR were observed. However, the expression levels of total ATM and ATR remained unchanged. Chk1 and Chk2 are often activated by ATM and ATR, resulting in a cascade of activation of further downstream signals. ${ }^{25,26}$ The study demonstrated that the expression levels of the phospho-Chk1 and phospho-Chk2 increased, indicating the involvement of ATM/ATR-Chk1/Chk2 signaling in $\mathrm{SH}$-induced DDR.

ROS contributes to SH-induced breast cancer DNA damage. As chemical cytotoxicity is usually related with endogenously generated ROS, ${ }^{27}$ we then examined whether $\mathrm{SH}$ could induce ROS in MDA-MB-231 and MCF-7 with a specific oxidation-sensitive fluorescent probe DCFH-DA. ROS increase was detected after $\mathrm{SH}$ treatment for $48 \mathrm{~h}$ (Figures $5 \mathrm{a}$ and b). NAC was used to explore the relationship between ROS generation and SH-induced DNA damage. Pretreatment with $5 \mathrm{mM} / \mathrm{N}$ NAC abrogated the ROS generation by $\mathrm{SH}$ (Figure $5 \mathrm{c}$ and Supplementary Figure S4). NAC pretreatment almost completely inhibited $\mathrm{SH}$-induced DNA damage (Figure 5d and Supplementary Figure S5d), suggesting that $\mathrm{SH}$ exerted at least some of its cytotoxic effects by increasing oxidative stress.

MAPK pathways are involved in the anti-tumor effects of SH. MAPK intracellular signaling cascades are implicated in breast diseases and function in mammary epithelial cells, ${ }^{20}$ and activation of MAPK pathways has been generally recognized for its important role in breast cancer growth. To figure out the underlying molecular signaling pathways by which $\mathrm{SH}$ exerted its anti-proliferation effect on cancer cells, we investigated the effects of $\mathrm{SH}$ on MAPK pathways in MDA-MB-231 and MCF-7. As the result shown, the expression levels of phospho-ERK, phospho-JNK and phospho-p38 were increased dose-dependently, whereas their total expression levels did not change (Figure $6 a$ and Supplementary Figure S5e). We then explored whether NAC pretreatment could abolish these changes. Cells were pretreated with $5 \mathrm{mM} / \mathrm{N} \mathrm{NAC}$ for $2 \mathrm{~h}$ before treatment with $1.0 \mu \mathrm{mol} / \mathrm{ml} \mathrm{SH}$ for $48 \mathrm{~h}$. We found that NAC pretreatment only attenuated $\mathrm{SH}$-induced expression levels of phosphoERK, phospho-JNK and phospho-p38 (Figure $6 \mathrm{~b}$ and Supplementary Figure S5e), implying that MAPKs were involved in both ROS-dependent and -independent pathways of $\mathrm{SH}$-induced breast cancer cell death.

SH suppresses tumor growth in vivo. Nude mice bearing MDA-MB-231 tumors were treated with physiological saline 

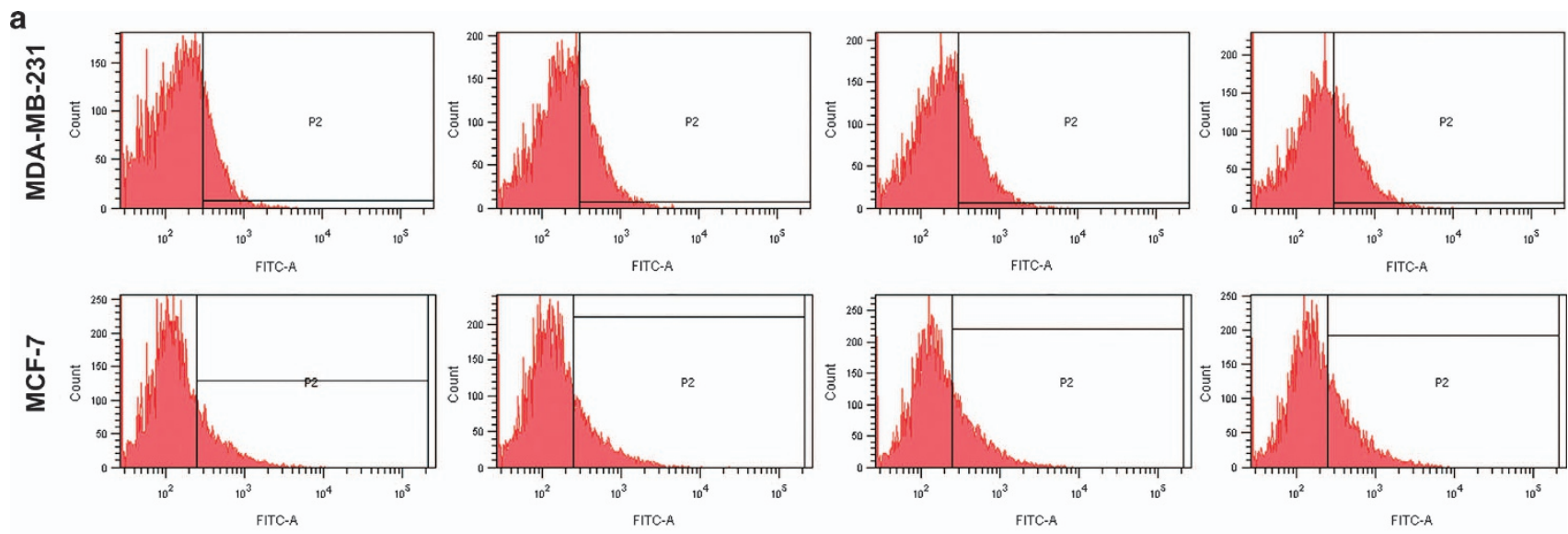

0

0.25

1.0

$\mathrm{SH}(\mu \mathrm{mol} / \mathrm{mL})$
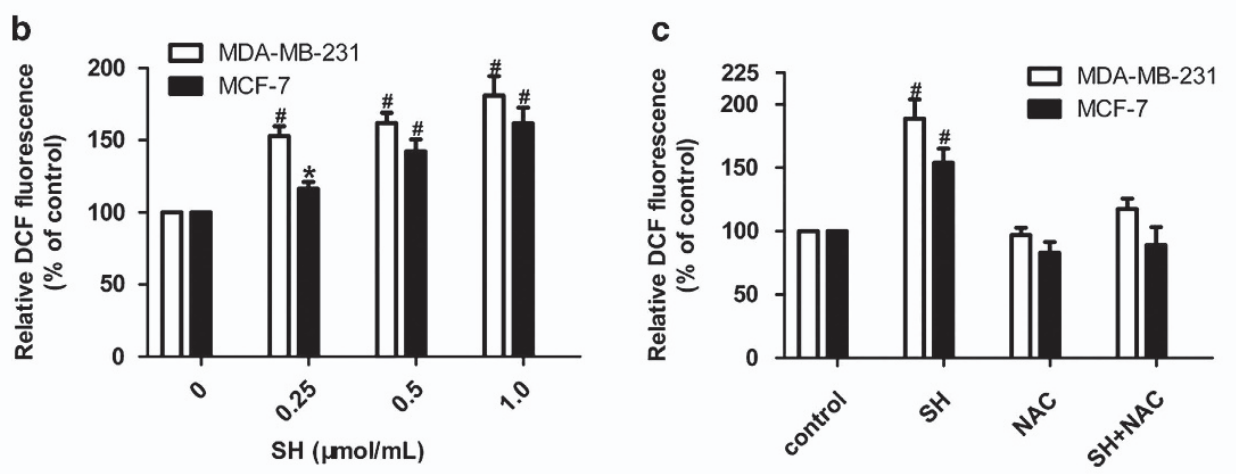

d

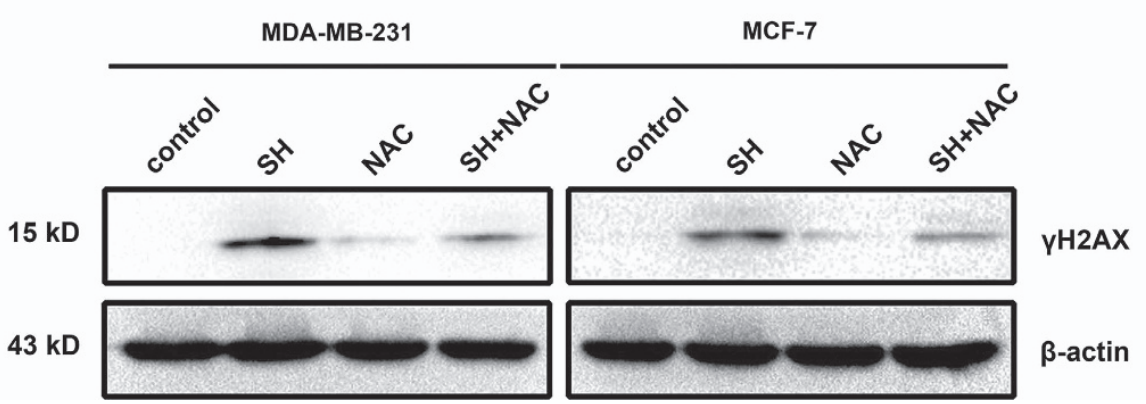

Figure 5 SH triggered ROS generation in breast cancer cells. (a and $\mathbf{b}$ ) DCFH-DA staining was used to detect ROS production in MDA-MB-231 and MCF-7. (c) Pretreatment of $5 \mathrm{mM} / \mathrm{INAC}$ for $2 \mathrm{~h}$ significantly abolished ROS generation induced by SH. Cells were treated with $1.0 \mu \mathrm{mol} / \mathrm{ml} \mathrm{SH}$ and $5 \mathrm{mM} / \mathrm{NAC}$, independently or in combination, and ROS level at $48 \mathrm{~h}$ was analyzed using a FACSCAN flow cytometer. Data are the means \pm S.D. of three independent experiments. ${ }^{*} P<0.05,{ }^{\#} P<0.01$, $\mathrm{SH}$-treated group compared with the untreated control group. (d) The ROS inhibition by NAC almost completely blocked the oxidative DNA damage. Equal protein loading was evaluated by $\beta$-actin. Representative data are shown from three independent experiments

or $\mathrm{SH}$ at a low dose $(75 \mathrm{mg} / \mathrm{kg}$ of body weight) or a high dose $(150 \mathrm{mg} / \mathrm{kg}$ of body weight) for 21 days. After treatment with $\mathrm{SH}$, no marked changes in body weight were found in all the groups (Figure 7a). Reductions in tumor volume (Figures 7b and c) and tumor weight (Figure $7 \mathrm{~d})$ were observed in the 75 and $150 \mathrm{mg} / \mathrm{kg}$ groups ( $P<0.05$ and $P<0.01$, respectively).

Consistent with the results of the in vitro experiments, PCNA, a proliferation marker of tumors, was significantly decreased in the SH-treated groups, and $\mathrm{Bax} / \mathrm{Bcl}-2$, an apoptosis implication of tumors, was remarkably increased after $\mathrm{SH}$ treatment. Specimens from the $\mathrm{SH}$-untreated group and $\mathrm{SH}$-treated groups were stained with phospho-ERK, phospho-JNK and phospho-p38. The results demonstrated that $\mathrm{SH}$ significantly increased the expression levels of phospho-ERK, phospho-JNK and phospho-p38 in tumors.

\section{Discussion}

Sinomenine, a pure alkaloid extracted from Sinomenium acutum Rehd. et Wils., ${ }^{9}$ is known to possess anti-inflammatory 


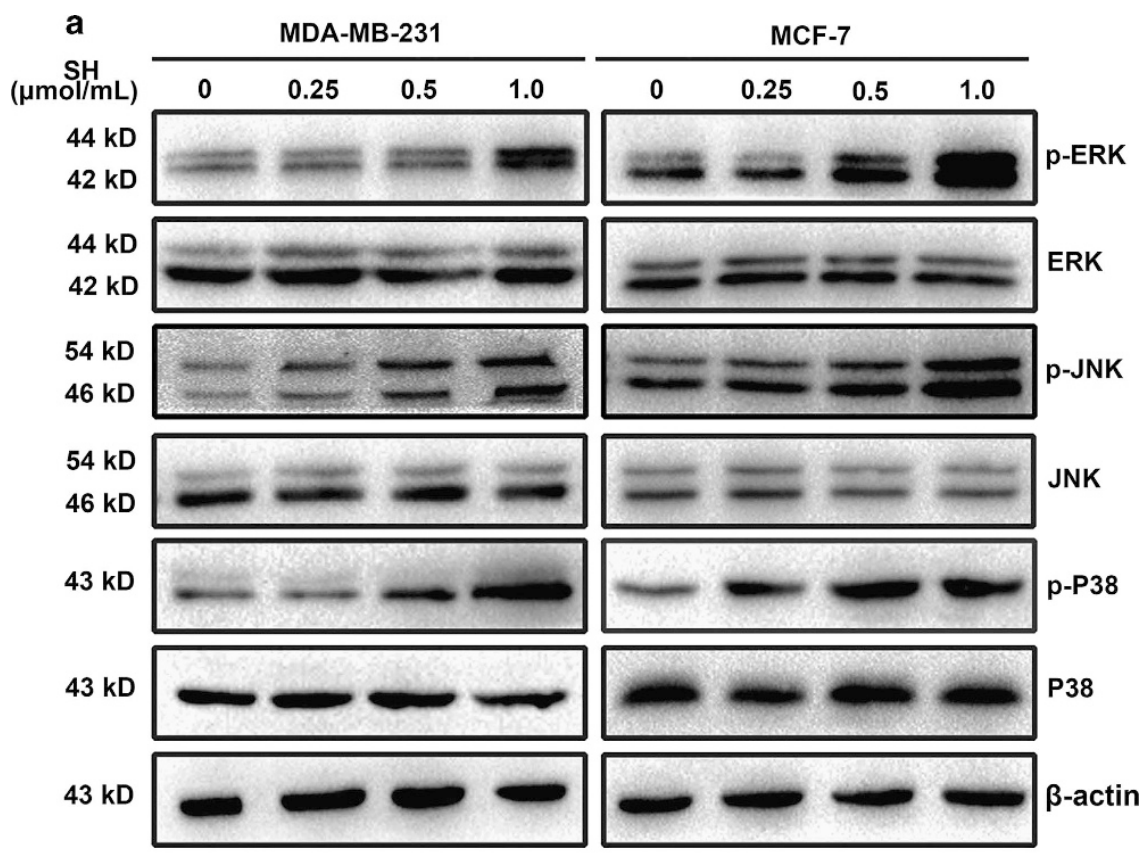

b

MDA-MB-231

MCF-7

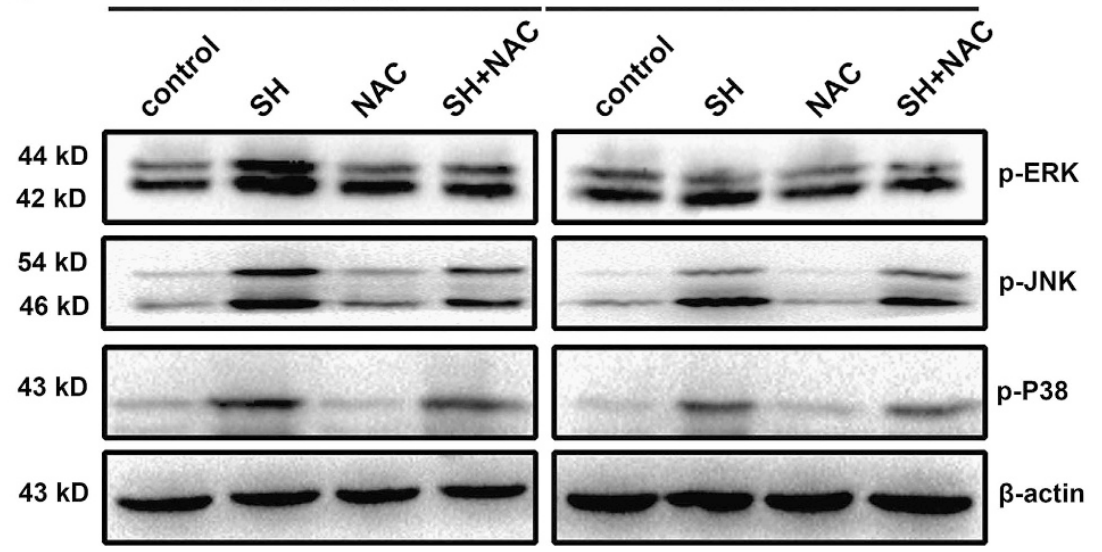

Figure 6 Involvement of MAPK pathways in anti-cancer effect of SH. (a) Cells were treated with SH $(0,0.25,0.5$ and $1.0 \mu \mathrm{mol} / \mathrm{ml})$ for $48 \mathrm{~h}$, and the whole-cell lysates were prepared. The expression levels of ERK1/2, phospho-ERK1/2, p38, phospho-p38, JNK and phospho-JNK were analyzed by western blotting. (b) Pretreatment of ROS scavenger NAC for $2 \mathrm{~h}$ inhibited SH-induced MAPK expression levels. Cells were treated with $1.0 \mu \mathrm{mol} / \mathrm{ml} \mathrm{SH}$ and $5 \mathrm{mM} / \mathrm{NAC}$, independently or in combination. The wholecell lysates were prepared to test the expression levels of phospho-ERK1/2, phospho-p38 and phospho-JNK. Equal protein loading was evaluated by $\beta$-actin. Representative data are shown from three independent experiments

and anti-immune effects. $\mathrm{SH}$, a hydrochloride chemical form of sinomenine, has recently been found to have an anti-proliferative effect on cancer cells. ${ }^{17-19}$ However, no clear mechanism has been provided for this effect. In this study, we evaluated the effects of SH on human breast cancer cells and investigated the possible underlying mechanism.

As uncontrolled proliferation of cancer cells have an important role in progression of cancers, ${ }^{28}$ we set out to investigate whether $\mathrm{SH}$ inhibited cancer cell proliferation. Our results demonstrated that $\mathrm{SH}$ inhibited $\mathrm{ER}(+) / \mathrm{PR}(+) \mathrm{MDA}-$ MB-231 and ER $(-) / P R(-)$ MCF-7 breast cancer cells in a time- and dose-dependent manner.

To clarify the underlying mechanisms for the antiproliferative effect of $\mathrm{SH}$, cell cycle and apoptosis were analyzed. Genetic lesions that dysfunction critical regulators of G1 phase progression in mammalian cells are present in most human cancers. Our results showed that $\mathrm{SH}$ treatment caused an increase in the percentage of cells blocked in G1 phase and a decrease in the percentage of cells in S phase or G2 phase. Cell cycle transitions are strictly regulated by a series of cell cycle-positive regulators and -negative regulators. In human cells, cyclin D1 interacts with CDK4 and CDK6 to form holoenzymes and then phosphorylates the tumorsuppressor protein $\mathrm{Rb}$ in $\mathrm{G} 1$ phase, which is important for cell cycle progression. ${ }^{29}$ The E2F transcription factor binds to $\mathrm{Rb}$ and is released when $\mathrm{Rb}$ is phosphorylated, inducing the expression levels of a series of genes, such as cyclin E, cyclin A, PCNA and MCM7, which are involved in entry into S phase of the cell division cycle. ${ }^{30}$ Our study showed that $\mathrm{SH}$ treatment downregulated the expression levels of the cell 
a

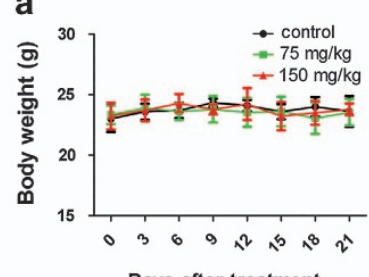

Days after treatment

C

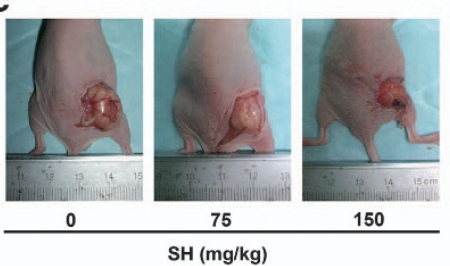

\section{b}

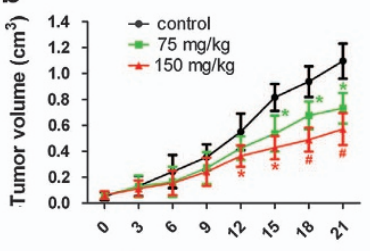

Days after treatment

d
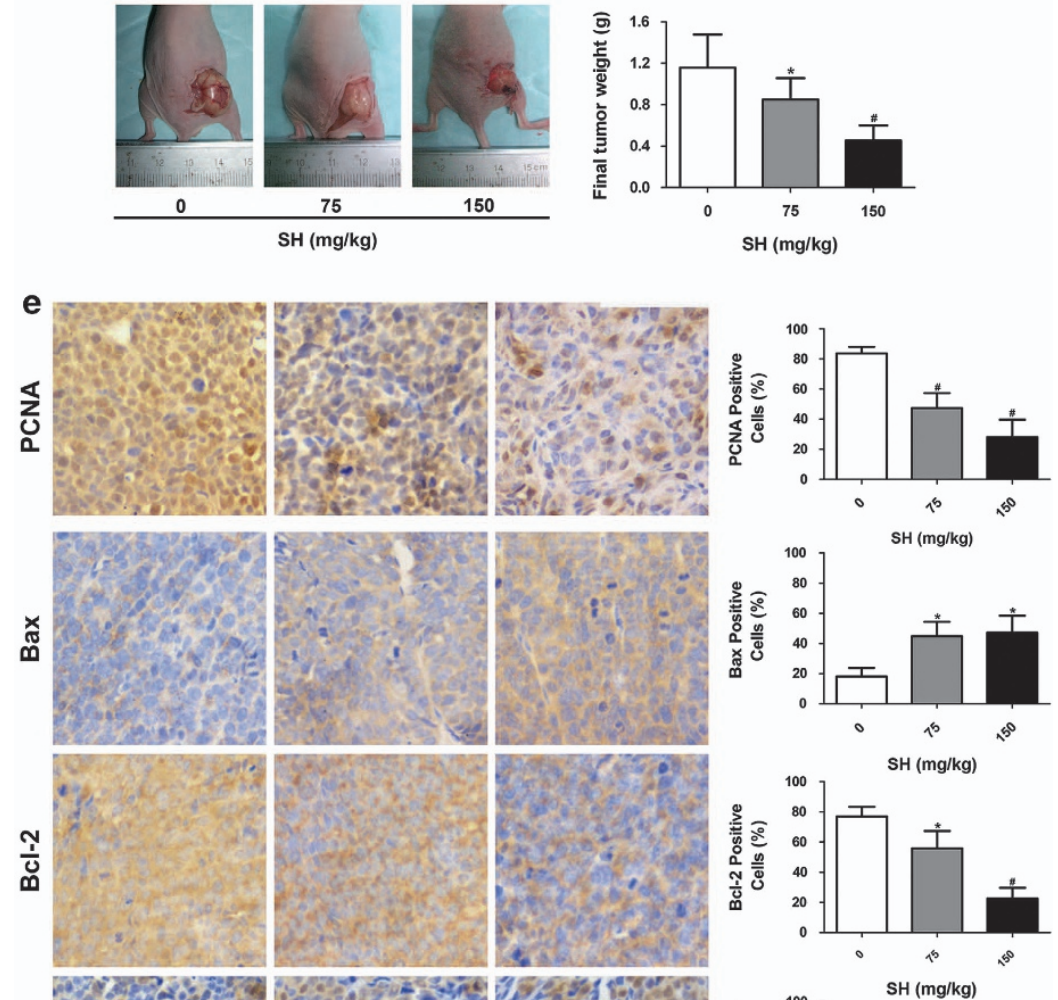

논
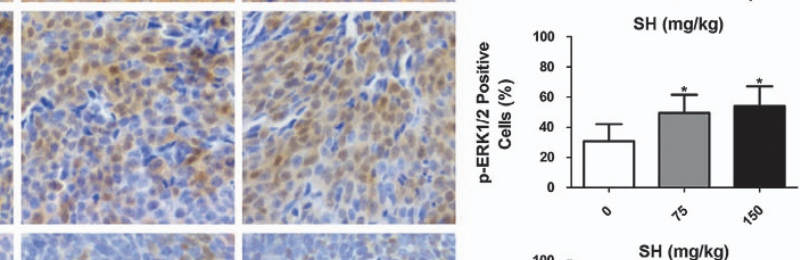

$\frac{x}{2}$
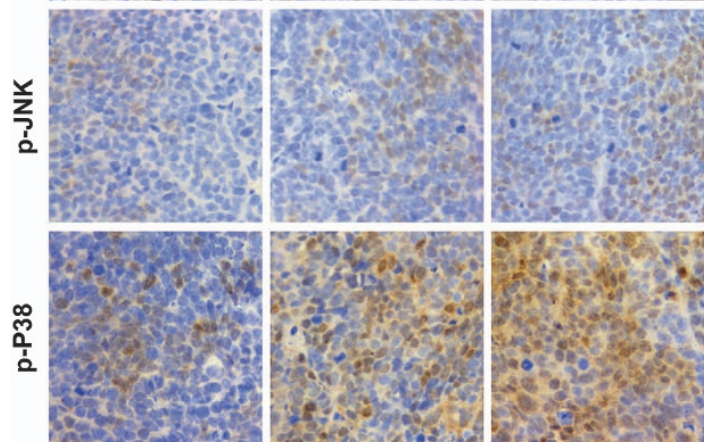

75

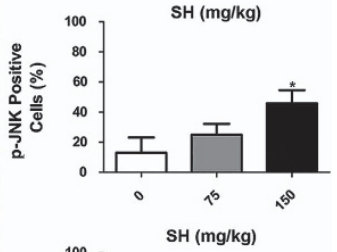

$\mathrm{SH}(\mathrm{mg} / \mathrm{kg})$
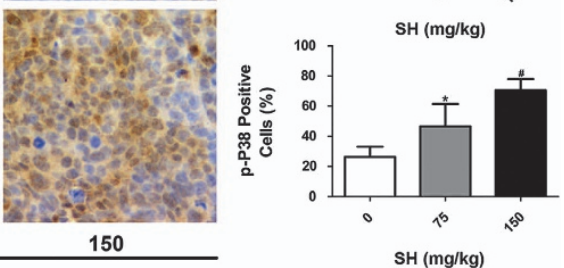

Figure 7 SH suppressed the growth of human breast tumors in vivo. Nude mice bearing MDA-MB-231 human breast xenografts were treated with physiological saline or $\mathrm{SH}$ at a low dose $(75 \mathrm{mg} / \mathrm{kg}$ of body weight) or a high dose $(150 \mathrm{mg} / \mathrm{kg}$ of body weight) for 21 days. (a) Body weight and (b) tumor volume were recorded every 3 days. (c) Representative tumor pictures are shown. (d) Tumor weight was evaluated on the twenty-first day. (e) Immunohistochemical staining of tumor specimens. Data are represented as mean \pm S.D. of six mice in each group. ${ }^{*} P<0.05$, ${ }^{\#} P<0.01$, SH-treated group compared with the untreated control group 
cycle-positive regulators, including CDK4, cyclin D1, cyclin E, phospho-Rb, PCNA and MCM7. The activity of cyclin-CDK complexes is inhibited by the Cip/Kip family, including p21, p27 and p57. ${ }^{31}$ This study showed that cell cycle-negative regulators p21 and p27 increased in cancer cells treated with $\mathrm{SH}$, which is consistent with the previous findings that $\mathrm{p} 21$ and p27 are tumor suppressors. ${ }^{32,33}$

Deregulated cell proliferation, together with suppressed apoptosis, provides the minimal platform upon which all neoplastic progression occurs. ${ }^{28}$ Two major pathways are responsible for cell apoptosis, namely the extrinsic pathway (death receptor pathway) and the intrinsic pathway (mitochondrial pathway). ${ }^{34}$ Cell apoptosis requires the activation and action of a set of cysteine proteases, named caspases, which are central effectors throughout the apoptotic process. ${ }^{23}$ Caspase- 8 and -10 are involved in the extrinsic pathway, while caspase- 3 is involved in the intrinsic pathway. The stability of $\Delta \psi \mathrm{m}$ is vital for cellular homeostasis. In the intrinsic pathway, when the $\Delta \psi \mathrm{m}$ is decreased, cytochrome $c$ released from the mitochondrial intermembrane space will lead to activation of caspase-9, which is regulated by anti-apoptotic $\mathrm{Bcl}-2$ and pro-apoptotic Bax. ${ }^{35}$ Both intrinsic and extrinsic pathways will eventually activate caspase-3, a predominant effector to cleave the signaling components that effect morphological changes associated with apoptosis. ${ }^{34}$ Our results demonstrated $\mathrm{SH}$ induced apoptosis through the intrinsic pathway, with an increase in the $\mathrm{Bax} / \mathrm{Bcl}-2$ ratio. SH treatment also caused the cleavage of PARP, a direct target of caspase-3 and an early marker of apoptosis. ${ }^{23}$ However, no increase in the p53 expression was found, although p53 has a crucial role in the regulation of cell cycle and apoptosis. In addition, no phospho-p53 was tested when we examined the phosphorylation of p53 at Ser15. These results indicated that $\mathrm{SH}$ inhibited breast cancer cells in a p53-independent way.

As DNA damage is a common cause of cell cycle arrest and apoptosis, we then examined whether SH could induce DNA damage. One of the earliest events in DNA damage is phosphorylation of histone $\mathrm{H} 2 \mathrm{AX}$ at Ser139 to create $\gamma-\mathrm{H} 2 \mathrm{AX}$, which forms nuclear foci and recruits DNA repair factors. ${ }^{24}$ Our results showed that $\mathrm{SH}$ increased $\gamma-\mathrm{H} 2 \mathrm{AX}$ expression in both MDA-MB-231 and MCF-7. DNA damage initiates DDR in cells, where proteins sense the damage, transduce the signals and mediate the cellular response through the action of effector kinases. Sensors like ATM or ATR activate a series of transducers, such as Chk1 and Chk2, which have an important part in determining cellular responses to DNA damage. Chk1 is primarily activated through phosphorylation on amino-acid residues Ser317 and Ser345 by ATR in response to DNA SSBs ${ }^{25}$ and is predominantly responsible for initiating cell cycle arrest, allowing time for DNA repair and cell survival. Chk2 is activated through phosphorylation of Thr68 by ATM in response to DNA DSBs. ${ }^{26}$ Then effectors in DDR respond to the transducers and determine the destiny of the cells, including slowing of the replication fork, causing cell cycle arrest, enhancing DNA repair and inducing apoptosis. ${ }^{36}$ We found that $\mathrm{SH}$ increased the phospho-ATM and phospho-ATR, while the total expression levels of ATM and ATR remained stable. Meanwhile, $\mathrm{SH}$ increased the phosphorylation forms of Chk1 and Chk2, implying the role of
ATM/ATR-Chk1/Chk2 pathways in SH-caused DNA damage. Overproduction of intracellular ROS could cause DNA damage, which is likely to trigger cell apoptosis. ${ }^{37}$ Our results demonstrated that $\mathrm{SH}$ could increase intracellular ROS production. NAC, a ROS scavenger, effectively abolished $\mathrm{SH}$-induced ROS generation and almost eliminated the oxidative DNA damage.

MAPK pathway is one of the major signaling involved in regulation of a wide range of cellular responses, including cell proliferation, differentiation and survival. ${ }^{38}$ ERK $1 / 2$ primarily functions in cell proliferation in comparison with its role in apoptosis, ${ }^{39}$ while activation of $\mathrm{JNK}^{40,41}$ and p38 MAPKs ${ }^{42}$ is generally associated with promotion of apoptosis. Research has proved that persistent overactivation of ERK1/2 induces cell cycle arrest. Abnormal hyper-activation of ERK1/2 throughout G1 phase leads to accumulation of p21 that inhibits cyclin E/CDK2 complexes to block cells from entering $\mathrm{S}$ phase, ${ }^{43}$ which may explain our result that $\mathrm{SH}$ induced activation of ERK1/2. P38 MAPK has been defined as a tumor suppressor for its role in cell differentiation, growth inhibition and apoptosis induction. ${ }^{42,44}$ Although less attention has been paid, p38 MAPK is also involved in regulating a number of key factors in G1/S cell cycle checkpoint. It has been reported that p38 MAPK can directly phosphorylate and stabilize p21, ${ }^{45}$ negatively regulate cyclin D1 at transcription level ${ }^{46}$ and trigger cyclin D1 ubiquitination. ${ }^{47} \mathrm{JNK}$ is a member of the MAPK family known for its role in triggering apoptosis by targeting a variety of genes, including $\mathrm{Bcl}-2$, Bax and cyclin D1. ${ }^{48-50}$ In our study, $\mathrm{SH}$ treatment upregulated the expression levels of phospho-ERK1/2, phospho-p38 and phospho-JNK but had no effect on the total levels of ERK1/2, p38 and JNK. Meanwhile, the oxidative DNA damage could be inhibited by NAC pretreatment, but the phosphorylation of MAPK signaling was only blocked to some extent, suggesting both ROS-dependent and -independent pathways were involved in MAPK-mediated cell death in $\mathrm{SH}$-treated cancer cells.

In summary, this is the first study, to our knowledge, to investigate the anti-proliferative effects of $\mathrm{SH}$ on breast cancer in vitro and in vivo and the potential molecular mechanisms for $\mathrm{SH}$-induced cell death. The main findings include the following: (1) $\mathrm{SH}$ treatment caused cell cycle arrest and apoptosis in breast cancer cells regardless of the ER and PR status; (2) SH induced ATM/Chk2 and ATR/ Chk1-mediated oxidative DNA damage; (3) ROS abolition almost blocked SH-induced DNA damage but only mitigated $\mathrm{SH}$-induced MAPK expression changes, suggesting that both ROS-dependent and -independent pathways were involved in MAPK-mediated SH-induced breast cancer cell death; and (4) the systemic administration of $\mathrm{SH}$ suppressed the growth of human breast cancer xenografts without showing significant toxicity. These findings suggest that $\mathrm{SH}$ may be used as a potential anti-tumor drug in breast cancer treatment.

\section{Materials and methods}

Reagents. SH was purchased from Zhengqing Pharmaceutical Group (Hunan, China). The antibodies against ERK1/2, phospho-ERK1/2 (Thr202/Tyr204), p38 MAPK, phospho-p38 MAPK (Thr180/Tyr182), JNK, phospho-JNK (Thr183/ Tyr185), p-Rb (Ser780), p-p53 (Ser15), p27, poly-ADP-ribose polymerase 
(PARP), Bax, ATM, phospho-ATM (Ser1981), ATR, phospho-ATR (Ser428), phospho-Chk1 (Thr345), phospho-Chk2 (Thr68) and phospho-histone H2A.X (Ser139) were purchased from Cell Signaling Technology (Beverly, MA, USA). The antibodies against cyclin D1, cyclin E, p21, CDK4, p53, Rb, MCM7 cytochrome $c, \mathrm{Bcl}-2, \mathrm{PCNA}, \beta$-actin and horse-radish peroxidase (HRP) conjugated anti-rabbit or mouse $\mathrm{IgG}$ were purchased from Santa Cruz Biotechnology (Santa Cruz, CA, USA). The antibody against Chk2 was from Epitomics (Burlingame, CA, USA). The antibodies against Chk1 and Cy3conjugated affinipure goat anti-rabbit IgG were from Proteintech (Wuhan, China). Annexin V-FITC Apoptosis Detection Kit was purchased from KeyGEN BioTECH (Nanjing, China).

Cell culture. Cell lines used in our study included human breast cancer cell lines (MDA-MB-231, MCF-7, SK-BR-3, ZR-75-30, BT474 and T47D), human lung cancer lines (H1299 and A549), human gastric cancer cell lines (SGC7901 and MKN-28), human hepatic cancer cell lines (HepG2 and HHCC), human renal cancer cell lines (786-O and 769-P), human cervical cancer cell lines (HeLa and SiHa), human colon cancer cell lines (SW480 and LoVo) and one normal human breast epithelial cell line (MCF-10A). MCF-10A was obtained from American Type Culture Collection (Manassas, VA, USA). Other cell lines were obtained from Shanghai Institute of Biochemistry and Cell Biology, Chinese Academy of Sciences (Shanghai, China). MCF-10A cells were propagated in DMEM/F12 medium containing $5 \%(\mathrm{v} / \mathrm{v})$ horse serum in the presence of $20 \mathrm{ng} / \mathrm{ml}$ epidermal growth factor, $10 \mu \mathrm{g} / \mathrm{ml}$ insulin, $0.5 \mathrm{mg} / \mathrm{ml}$ hydrocortisone, $100 \mathrm{ng} / \mathrm{ml}$ cholera toxin, $100 \mathrm{U} / \mathrm{ml}$ penicillin and $100 \mu \mathrm{g} / \mathrm{ml}$ streptomycin. Other cells were cultured in DMEM or RPMI-1640 or DMEM/F12 supplemented with $10 \%(\mathrm{v} / \mathrm{v}) \mathrm{FBS}, 100 \mathrm{U} / \mathrm{ml}$ penicillin and $100 \mu \mathrm{g} / \mathrm{ml}$ streptomycin. All cells were incubated at $37^{\circ} \mathrm{C}$ in an incubator with $5 \% \mathrm{CO}_{2}$ and saturated humidity.

Cell viability assay. The exponentially growing cells $\left(5.0 \times 10^{3}\right.$ cells/well $)$ were plated into 96-well plates (Corning, Corning, NY, USA). Twenty-four hours after seeding, cells were incubated in the media with different concentrations of $\mathrm{SH}$ for the indicated time at $37^{\circ} \mathrm{C}$. Then, $20 \mu \mathrm{l}$ MTT solution $(5 \mathrm{~g} / \mathrm{l})$ was added into each well and incubated for additional $4 \mathrm{~h}$ at $37^{\circ} \mathrm{C}$. Then the media was removed, and formazan crystals were dissolved in $200 \mu \mathrm{l}$ DMSO. The absorbance was measured by a microplate reader (PerkinElmer, Waltham, MA, USA) at $570 \mathrm{~nm}$

Colony-formation assay. Cell colony-formation assay was used to assess the effect of SH on the reproductive potential of breast cancer cell lines. Briefly, cells were treated with different concentrations of SH for $48 \mathrm{~h}$ and collected by trypsinization. Cells were reseeded in 100-mm cell culture dishes with 200 cells per dish and cultured for another 10 days. Then, cells were fixed using $4 \%$ paraformaldehyde and stained with $0.5 \%$ crystal violet.

Morphological changes. Cells were treated with $\mathrm{SH}$ at $0,0.25,0.5$ and $1.0 \mu \mathrm{mol} / \mathrm{ml}$ for $48 \mathrm{~h}$. The culture medium was changed and morphological changes of cells were observed using phase-contrast microscopy (Leica, Heidelberg, Germany).

Cell cycle analysis. Cells were seeded in six-well plates (Corning) and treated with different concentrations of $\mathrm{SH}$. Then cells were collected at the indicated time. Samples of at least $1 \times 10^{6}$ cells were fixed in ice-cold $70 \%$ ethanol for at least $2 \mathrm{~h}$ at $4{ }^{\circ} \mathrm{C}$, washed twice with PBS and stained with a solution containing $50 \mu \mathrm{g} / \mathrm{ml} \mathrm{PI}$ and $50 \mu \mathrm{g} / \mathrm{ml} \mathrm{RNase}$ at room temperature for $30 \mathrm{~min}$. Cell cycle was analyzed with a FACScan flow cytometer (Becton Dickinson, San Jose CA, USA). The cell cycle distribution was evaluated on DNA plots by the CellQuest software (Becton Dickinson).

Senescence-associated $\beta$-galactosidase (SA- $\beta$-Gal) staining assay. SA- $\beta$-Gal staining assay was performed using an SA- $\beta$-Gal Staining Kit (Beyotime, Jiangsu, China). Briefly, after treatment with $\mathrm{SH}$, cells were washed with PBS and fixed $4 \%(\mathrm{v} / \mathrm{v})$ formaldehyde for $15 \mathrm{~min}$. Then cells were stained with SA- $\beta$-Gal staining solution at $\mathrm{pH} 6.0$ at $37^{\circ} \mathrm{C}$ overnight. Cells with a bright green or blue were regarded as positive.

Annexin V apoptosis assay. Cells were treated with different concentrations of SH. After the indicated time, cells were harvested and washed twice with ice-cold PBS. Then cells were suspended in binding buffer and incubated with annexinV-FITC and PI according to the manufacturer's instructions. Finally, samples were analyzed on a FACScan flow cytometer provided with the CellQuest software (Becton Dickinson).

$\Delta \psi \mathrm{m}$ detection. $\Delta \psi \mathrm{m}$ was analyzed with a fluorescent dye JC-1 (Beyotime). Cells were treated with $\mathrm{SH}$ and incubated for the indicated time. Then cells were collected by trypsinization and resuspended in fresh medium. Samples were added with $0.5 \mathrm{ml} \mathrm{JC}$-1 working solution and incubated for $20 \mathrm{~min}$ at $37^{\circ} \mathrm{C}$ in the dark. Then cells were washed with JC-1 staining buffer twice. Fluorescence of cells was analyzed with FACScan flow cytometer (Becton Dickinson), and mitochondrial depolarization was calculated as an increase in the green/red fluorescence intensity ratio.

Caspase activity. The activities of caspase- $3,-8$ and -9 were assessed using the Caspase-3, -8, and -9 Colorimetric Assay kits (KeyGen, Nanjing, China), respectively. The assay for detection of caspase activity is based on the ability of the active enzyme to cleave the chromophore $\mathrm{p}$-nitroanilide (pNA) from the labeled substrate DEVD-pNA. Briefly, cell lysates were prepared after treatment according to the manufacturer's protocol. Samples were added to the reaction mixture containing dithiothreitol and the substrate for caspase- $-3,-8$ or -9 and incubated for $4 \mathrm{~h}$ at $37^{\circ} \mathrm{C}$. Absorbance of the chromephore pNA was measured by a microplate reader (PerkinElmer) at $405 \mathrm{~nm}$. Activity of caspase-3, -8 or -9 was normalized to the amount of protein in the cell extracts, which was estimated by the method of Bradford.

Immunofluorescence staining of $\gamma \mathbf{H} 2 \mathrm{AX}$. Cells were grown on coverslips and treated with $\mathrm{SH}$ for $48 \mathrm{~h}$. After washing with PBS, cells were fixed with $4 \%$ paraformaldehyde for 10 min and permeabilized in PBS with $0.1 \%$ TritonX-100. Then cells were blocked with $3 \%$ BSA at room temperature for $1 \mathrm{~h}$. Primary antibody ( $\gamma \mathrm{H} 2 \mathrm{AX}$ at 1400 dilution) incubation was performed overnight at $4{ }^{\circ} \mathrm{C}$. After washing with PBS for three times, cells were incubated with secondary antibodies and counterstained with DAPI. Images were captured under a confocal microscopy (Leica).

Measurement of ROS. Intracellular ROS generation was measured using the Reactive Oxygen Species Assay Kit (Beyotime). After SH treatment, cells were stained with $10 \mu \mathrm{M} / \mathrm{IDCFH}-\mathrm{DA}$ at $37^{\circ} \mathrm{C}$ for $30 \mathrm{~min}$. Then cells were washed with serum-free DMEM for three times and collected for FACScan flow cytometer analysis (Becton Dickinson).

Western blotting assay. After treatment with the indicated concentrations of SH for $48 \mathrm{~h}$, cells were lysed in RIPA Lysis Buffer (Pioneer Technology, Xi'an, China) with protease inhibitor cocktail tablets and phosphatase inhibitor cocktail tables (Roche, Mannheim, Germany). Then cell lysates were centrifuged at $12000 \times g$ for $20 \mathrm{~min}$ at $4^{\circ} \mathrm{C}$. The supernatant was harvested, and the protein concentration was determined using a Pierce BCA protein assay kit (Thermo Scientific, Fremont, CA, USA). An equivalent amount of protein was separated by SDS-PAGE and transferred to polyvinyldifluoride membranes (Millipore, Billerica, MA, USA). The membranes were blocked with $5 \%(\mathrm{w} / \mathrm{v})$ nonfat powered milk in TBST ( $1 \mathrm{M}$ Tris buffer saline, pH 7.4, $5 \mathrm{M} \mathrm{NaCl}, 0.1 \%$ Tween-20) for $1 \mathrm{~h}$ at $37^{\circ} \mathrm{C}$. Then the membranes were probed with the primary antibodies overnight at $4{ }^{\circ} \mathrm{C}$, followed by a secondary anti-rabbit or mouse IgG conjugated with HRP. Signals were detected using chemiluminescence reagent (Millipore) and ChemiDoc System (Bio-Rad, Hercules, CA, USA).

In vivo tumor model. All animal procedures were performed according to the protocol approved by the Institutional Animal Care and Use Committee at Xi'an Jiaotong University. Four-week-old female BALB/C athymic nude mice with body weights approximately $20 \mathrm{~g}$ were purchased from Shanghai SLAC Laboratory Animal Co. Ltd. (Shanghai, China) and housed in the Laboratory Animal Centre of Xi'an Jiaotong University. After 1 week's acclimation, nude mice were subcutaneously injected at the right flanks with MDA-MB-231 human breast cancer cells $\left(2 \times 10^{6}\right)$ resuspended in $0.1 \mathrm{ml}$ serum- and antibiotic-free DMEM (1:1 Matrigel and medium). When tumors reached a size of $50 \mathrm{~mm}^{3}$, the mice were randomly assigned to three groups of six animals. Animals in the control group were intraperitoneally (i.p.) injected with $0.1 \mathrm{ml}$ physiological saline per $10 \mathrm{~g}$ body weight daily, and the treatment groups were injected i.p. with SH at doses of 75 or $150 \mathrm{mg} / \mathrm{kg}$ of body weight, 
dissolved in physiological saline. Tumor sizes were measured twice or three times a week using calipers, and tumor volumes were calculated according to the standard formula: width ${ }^{2} \times$ length/2 and expressed as $\mathrm{mm}^{3}$. After a total of 21 days of treatment, mice were killed, and tumor tissues were immediately removed, weighted and fixed in $4 \%$ paraformaldehyde for immnohistochemiscal analysis.

Immunohistochemistry. Tumor specimens were embedded into paraffin and the paraffin sections (4-mm thick) were stained with hematoxylin and erosin or immunostained with PCNA $(1: 250)$, Bax $(1: 250), \operatorname{Bcl}-2$ (1:100), p-ERK1/2 (1:400), p-p38 MAPK (1:1000) and p-JNK (1:100). Images were captured using a microscopy (Leica). The intensity of the staining was scored as 1 (negative), 2 (weakly positive), 3 (moderately positive) or 4 (strongly positve). The extent of the staining was categorized as 1 (stained cells: $1-25 \%), 2(26-50 \%), 3(51-75 \%)$ or $4(76-100 \%)$. The final staining score was the product of the intensity and the extent scores. Images of five random fields were taken from each specimen for quantitative analysis.

Statistical analysis. All data are expressed as mean \pm S.D. from at least three independent experiments. ANOVA, followed by multiple comparison post hoc test, or Kruskal-Wallis, was used to compare differences between the control and treatment groups. $P$-values $<0.05\left({ }^{*}\right)$ or $<0.01$ (\#) were considered as statistically significant.

\section{Conflict of Interest}

The authors declare no conflict of interest.

Acknowledgements. This study is supported by a grant from the National Nature Science Foundation of China (No. 81173613) and a grant from the First Affiliated Hospital of Xi'an Jiaotong University (No.12ZD29).

1. Porter P. 'Westernizing' women's risks? Breast cancer in lower-income countries. New Engl J Med 2008; 358: 213-216.

2. Anderson BO, Jakesz R. Breast cancer issues in developing countries: an overview of the Breast Health Global Initiative. World J Surg 2008; 32: 2578-2585.

3. Benson JR, Jatoi I. The global breast cancer burden. Future Oncol 2012; 8: 697-702.

4. Siegel R, Naishadham D, Jemal A. Cancer statistics, 2013. CA Cancer J Clin 2013; 63 : 11-30.

5. Redig AJ, McAllister SS. Breast cancer as a systemic disease: a view of metastasis. J Intern Med 2013; 274: 113-126.

6. O'Driscoll L, Clynes M. Biomarkers and multiple drug resistance in breast cancer. Curr Cancer Drug Targets 2006; 6: 365-384.

7. Brower V. Back to nature: extinction of medicinal plants threatens drug discovery. J Nat/ Cancer Inst 2008; 100: 838-839.

8. Li JWH, Vederas JC. Drug discovery and natural products: end of an era or an endless frontier? Science 2009; 325: 161-165.

9. Yamasaki H. Pharmacology of sinomenine, an anti-rheumatic alkaloid from Sinomenium acutum. Acta Med Okayama 1976; 30: 1-20.

10. Chen YW, Yang CY, Jin NS, Xie ZY, Fei L, Jia ZC et al. Sinomenine promotes differentiation but impedes maturation and co-stimulatory molecule expression of human monocyte-derived dendritic cells. Int Immunopharmacol 2007; 7: 1102-1110.

11. Wang $Y$, Fang YF, Huang WH, Zhou X, Wang MH, Zhong B et al. Effect of sinomenine on cytokine expression of macrophages and synoviocytes in adjuvant arthritis rats. $J$ Ethnopharmacol 2005; 98: 37-43.

12. Song SH, Shen XY, Tang Y, Wang ZX, Guo WY, Ding GS et al. Sinomenine pretreatment attenuates cold ischemia/reperfusion injury in rats: the role of heme oxygenase-1. Int Immunopharmacol 2010; 10: 679-684.

13. Wu WN, Wu PF, Chen XL, Zhang Z, Gu J, Yang YJ et al. Sinomenine protects against ischaemic brain injury: involvement of co-inhibition of acid-sensing ion channel 1a and L-type calcium channels. Br J Pharmacol 2011; 164: 1445-1459.

14. Qian L, Xu Z, Zhang W, Wilson B, Hong JS, Flood PM. Sinomenine, a natural dextrorotatory morphinan analog, is anti-inflammatory and neuroprotective through inhibition of microglial NADPH oxidase. J Neuroinflamm 2007; 19: 4-23.

15. Wang MH, Chang CK, Cheng JH, Wu HT, Li YX, Cheng JT. Activation of opioid mu-receptor by sinomenine in cell and mice. Neurosci Lett 2008; 443: 209-212.

16. Xu M, Liu L, Qi C, Deng B, Cai X. Sinomenine versus NSAIDs for the treatment of rheumatoid arthritis: a systematic review and meta-analysis. Planta Med 2008; 74: 1423-1429.
17. Li XJ, Yue PYK, Ha WY, Wong DYL, Tin MMY, Wang PX et al. Effect of sinomenine on gene expression of the IL-1 beta-activated human synovial sarcoma. Life Sci 2006; 79: $665-673$.

18. Jiang TS, Zhou LP, Zhang WL, Qu D, Xu XM, Yang Y et al. Effects of sinomenine on proliferation and apoptosis in human lung cancer cell line $\mathrm{NCl}-\mathrm{H} 460$ in vitro. Mol Med Rep 2010; 3: 51-56.

19. Lu XL, Zeng J, Chen YL, He PM, Wen MX, Ren MD et al. Sinomenine hydrochloride inhibits human hepatocellular carcinoma cell growth in vitro and in vivo: involvement of cell cycle arrest and apoptosis induction. Int J Oncol 2013; 42: 229-238.

20. Whyte J, Bergin O, Bianchi A, McNally S, Martin F. Key signalling nodes in mammary gland development and cancer mitogen-activated protein kinase signalling in experimental models of breast cancer progression and in mammary gland development. Breast Cancer Res 2009; $11: 5$.

21. Milde-Langosch K, Bamberger AM, Rieck G, Grund D, Hemminger G, Muller V et al. Expression and prognostic relevance of activated extracellular-regulated kinases (ERK1/2) in breast cancer. Br J Cancer 2005; 92: 2206-2215.

22. Muscella A, Vetrugno C, Fanizzi FP, Manca C, De Pascali SA, Marsigliante S. A new platinum(II) compound anticancer drug candidate with selective cytotoxicity for breast cancer cells. Cell Death Dis 2013; 4: e796.

23. Thornberry NA, Lazebnik Y. Caspases: enemies within. Science 1998; 281: 1312-1316.

24. Burma S, Chen BP, Murphy M, Kurimasa A, Chen DJ. ATM phosphorylates histone H2AX in response to DNA double-strand breaks. J Biol Chem 2001; 276: 42462-42467.

25. Guo Z, Kumagai A, Wang SX, Dunphy WG. Requirement for Atr in phosphorylation of Chk1 and cell cycle regulation in response to DNA replication blocks and UV-damaged DNA in Xenopus egg extracts. Genes Dev 2000; 14: 2745-2756.

26. Melchionna R, Chen XB, Blasina A, McGowan $\mathrm{CH}$. Threonine 68 is required for radiationinduced phosphorylation and activation of Cds1. Nat Cell Biol 2000; 2: 762-765.

27. Qi XF, Zheng L, Lee KJ, Kim DH, Kim CS, Cai DQ et al. HMG-CoA reductase inhibitors induce apoptosis of lymphoma cells by promoting ROS generation and regulating Akt, Erk and p38 signals via suppression of mevalonate pathway. Cell Death Dis 2013; 4: e518.

28. Evan Gl, Vousden KH. Proliferation, cell cycle and apoptosis in cancer. Nature 2001; 411: 342-348.

29. Ewen ME, Sluss HK, Sherr CJ, Matsushime H, Kato JY, Livingston DM. Functional interactions of the retinoblastoma protein with mammalian D-type cyclins. Cell 1993; 73: 487-497.

30. Sherr CJ. The Pezcoller Lecture: cancer cell cycles revisited. Cancer Res 2000; 60: 3689-3695.

31. Besson A, Dowdy SF, Roberts JM. CDK inhibitors: cell cycle regulators and beyond. Dev Cell 2008; 14: 159-169.

32. Liu Y, Yeh N, Zhu XH, Leversha M, Cordon-Cardo C, Ghossein R et al. Somatic cell type specific gene transfer reveals a tumor-promoting function for p21(Waf1/Cip1). EMBO J 2007; 26: 4683-4693.

33. Fero ML. Hot papers - Cell biology - A syndrome of multiorgan hyperplasia with features of gigantism, tumorigenesis, and female sterility in p27(Kip1)-deficient mice by M.L. Fero, M. Rivkin, M. Tasch, P. Porter, C.E. Carow, E. Firpo, K. Polyak, L.H. Tsai, V. Broudy, R.M. Perlmutter, K. Kaushansky, J.M. Roberts - Comments. Scientist 1998; 12: 11-11.

34. Jin ZY, El-Deiry WS. Overview of cell death signaling pathways. Cancer Biol Ther 2005; 4 : $139-163$.

35. Adams JM, Cory S. The Bcl-2 protein family: arbiters of cell survival. Science 1998; 281 : 1322-1326.

36. Zhou BB, Elledge SJ. The DNA damage response: putting checkpoints in perspective Nature 2000; 408: 433-439.

37. Vaux DL, Korsmeyer SJ. Cell death in development. Cell 1999; 96: 245-254.

38. Su B, Karin M. Mitogen-activated protein kinase cascades and regulation of gene expression. Curr Opin Immunol 1996; 8: 402-411.

39. Roovers K, Assoian RK. Integrating the MAP kinase signal into the G1 phase cell cycle machinery. Bioessays 2000; 22: 818-826.

40. Herr I, Wilhelm D, Meyer E, Jeremias I, Angel P, Debatin KM. JNK/SAPK activity contributes to TRAIL-induced apoptosis. Cell Death Differ 1999; 6: 130-135.

41. Sanchez-Perez I, Murguia JR, Perona R. Cisplatin induces a persistent activation of JNK that is related to cell death. Oncogene 1998; 16: 533-540.

42. Frasch SC, Nick JA, Fadok VA, Bratton DL, Worthen GS, Henson PM p38 mitogen-activated protein kinase-dependent and -independent intracellular signal transduction pathways leading to apoptosis in human neutrophils. J Biol Chem 1998; 273: 8389-8397.

43. Park JS, Qiao L, Gilfor D, Yang MY, Hylemon PB, Benz C et al. A role for both Ets and C/ EBP transcription factors and mRNA stabilization in the MAPK-dependent increase in p21(Cip1/WAF1/mda6) protein levels in primary hepatocytes. Mol Biol Cell 2000; 11: 2915-2932.

44. Hui LJ, Bakiri L, Stepniak E, Wagner EF. p38 alpha - A suppressor of cell proliferation and tumorigenesis. Cell Cycle 2007; 6: 2429-2433.

45. Kim GY, Mercer SE, Ewton DZ, Yan ZF, Jin K, Friedman E. The stress-activated protein kinases p38 alpha and JNK1 stabilize p21(Cip1) by phosphorylation. J Biol Chem 2002; 277: 29792-29802.

46. Yee AS, Paulson EK, McDevitt MA, Rieger-Christ K, Summerhayese I, Berasi SP et al. The HBP1 transcriptional repressor and the p38 MAP kinase: unlikely partners in G1 regulation and tumor suppression. Gene 2004; 336: 1-13. 
47. Casanovas O, Miro B, Estanyol JM, Itarte E, Agell N, Bachs O. Osmotic stress regulates the stability of cyclin D1 in a p38(SAPK2)-dependent manner. J Biol Chem 2000; 275: 35091-35097.

48. Maundrell K, Antonsson B, Magnenat E, Camps M, Muda M, Chabert C et al. Bcl-2 undergoes phosphorylation by C-Jun N-terminal kinase stress-activated protein kinases in the presence of the constitutively active GTP-binding protein Rac1. J Biol Chem 1997; 272: 25238-25242.

49. Miller TM, Moulder KL, Knudson CM, Creedon DJ, Deshmukh M, Korsmeyer SJ et al. Bax deletion further orders the cell death pathway in cerebellar granule cells and suggests a caspase-independent pathway to cell death. J Cell Biol 1997; 139: 205-217.

50. Kranenburg O, vanderEb A, Zantema A. Cyclin D1 is an essential mediator of apoptotic neuronal cell death. EMBO J 1996; 15: 46-54.
Cell Death and Disease is an open-access journal published by Nature Publishing Group. This work is licensed under a Creative Commons Attribution-NonCommercialNoDerivs 3.0 Unported License. The images or other third party material in this article are included in the article's Creative Commons license, unless indicated otherwise in the credit line; if the material is not included under the Creative Commons license, users will need to obtain permission from the license holder to reproduce the material. To view a copy of this license, visit http://creativecommons.org/icenses/ by-nc-nd/3.0/

Supplementary Information accompanies this paper on Cell Death and Disease website (http://www.nature.com/cddis) 